Published in final edited form as:

Toxicol Lett. 2015 August 19; 237(1): 21-29. doi:10.1016/j.toxlet.2015.05.012.

\title{
Differential cytotoxicity of long-chain bases for human oral gingival epithelial keratinocytes, oral fibroblasts, and dendritic cells
}

\author{
Christopher Poulsen $^{\mathrm{a}}$, Leslie A. Mehalick ${ }^{\mathrm{a}}$, Carol L. Fischer ${ }^{\mathrm{b}}$, Emily A. Lanzel ${ }^{\mathrm{c}}$, Amber M. \\ Bates $^{b}$, Katherine S. Walters ${ }^{d}$, Joseph E. Cavanaugh ${ }^{\mathrm{e}}$, Janet M. Guthmiller ${ }^{\mathrm{f}}$, Georgia K. \\ Johnson ${ }^{a}$, Philip W. Wertz ${ }^{b, c}$, and Kim A. Brogden ${ }^{a, b, *}$ \\ aDepartment of Periodontics, College of Dentistry, The University of lowa, lowa City, IA 52242, \\ USA
}

bDows Institute for Dental Research, College of Dentistry, The University of lowa, lowa City, IA 52242, USA

'Department of Oral Pathology, Radiology and Medicine, College of Dentistry, The University of lowa, lowa City, IA 52242, USA

${ }^{d}$ Central Microscopy Research Facility, The University of lowa, lowa City, IA 52242, USA

eDepartment of Biostatistics, College of Public Health, The University of lowa, lowa City, IA 52242, USA

${ }^{\mathrm{f} C o l l e g e}$ of Dentistry, University of Nebraska Medical Center, $40^{\text {th }}$ and Holdrege, Lincoln, NE 68583, USA

\section{Abstract}

Long-chain bases are present in the oral cavity. Previously we determined that sphingosine, dihydrosphingosine, and phytosphingosine have potent antimicrobial activity against oral pathogens. Here, we determined the cytotoxicities of long-chain bases for oral cells, an important step in considering their potential as antimicrobial agents for oral infections. This information would clearly help in establishing prophylactic or therapeutic doses. To assess this, human oral

\footnotetext{
(C) 2015 Published by Elsevier Ireland Ltd.

*Corresponding author at: N423 DSB, College of Dentistry, 801 Newton Road, The University of Iowa, Iowa City, IA 52242, USA. Tel.: +1 319335 8077. kim-brogden@uiowa.edu.

Authors' Contribution

Christopher Poulsen, Leslie Mehalick, Carol L. Fischer, and Kim A. Brogden conceived the project. Carol L. Fischer and Amber Bates performed the in vitro cytotoxicity assays, recorded the data, and graphed the results. Katherine S. Walters assisted with the confocal microscopy. Emily A. Lanzel performed the histology and immunohistochemical staining of the keratinocytes and fibroblasts. Janet M. Guthmiller and Georgia K. Johnson wrote the IRB, met with the subjects, collected excess surgical tissues, and isolated the keratinocytes and fibroblasts. Philip W. Wertz prepared the lipids and determined their purity with thin layer chromatography. Joseph E. Cavanaugh supervised the statistical analysis.

Publisher's Disclaimer: This is a PDF file of an unedited manuscript that has been accepted for publication. As a service to our customers we are providing this early version of the manuscript. The manuscript will undergo copyediting, typesetting, and review of the resulting proof before it is published in its final citable form. Please note that during the production process errors may be discovered which could affect the content, and all legal disclaimers that apply to the journal pertain.

Conflicts of interests

There are no competing conflicts of interests. None of the authors have personal relationships with other people or organisations that can inappropriately influence or bias their actions.
} 
gingival epithelial (GE) keratinocytes, oral gingival fibroblasts (GF), and dendritic cells (DC) were exposed to 10.0-640.0 $\mu \mathrm{M}$ long-chain bases and glycerol monolaurate (GML). The effects of long-chain bases on cell metabolism (conversion of resazurin to resorufin), membrane permeability (uptake of propridium iodide or SYTOX-Green), release of cellular contents (LDH), and cell morphology (confocal microscopy) were all determined. GE keratinocytes were more resistant to long-chain bases as compared to GF and DC, which were more susceptible. For DC, 0.2 to $10.0 \mu \mathrm{M}$ long-chain bases and GML were not cytotoxic; 40.0 to $80.0 \mu \mathrm{M}$ long-chain bases, but not GML, were cytotoxic; and $80.0 \mu \mathrm{M}$ long-chain bases induced cellular damage and death in less than 20 minutes. The $\mathrm{LD}_{50}$ of long-chain bases for GE keratinocytes, GF, and DC were considerably higher than their minimal inhibitory concentrations for oral pathogens, a finding important to pursuing their future potential in treating periodontal and oral infections.

\section{Introduction}

Saliva contains neutral lipids; cholesterol; mono-, di-, and tri-glycerides; free fatty acids; wax esters; cholesterol esters; squalene; and long-chain sphingoid bases (Brasser et al., 2010; Brasser et al., 2011a; Brasser et al., 2011b; Defago et al., 2011; Kensche et al., 2013; Larsson et al., 1996; Palmerini et al., 2011). Many of these lipids have innate immune functions: they are antimicrobial, influence the interaction of oral microorganisms with the salivary pellicle, impede microbial adherence to oral surfaces, and create a hydrophobic layer protecting teeth from demineralization (Bibel et al., 1992; Kensche et al., 2013).

The long-chain bases sphingosine, dihydrosphingosine, and phytosphingosine have variable antimicrobial activity against a variety of Gram-positive and Gram-negative bacteria including Escherichia coli, Staphylococcus aureus, and Corynebacterium species (Fischer et al., 2012; Fischer et al., 2013) and more potent antimicrobial activity against oral bacteria including Streptococcus sanguinis, Streptococcus mitis, Fusobacterium nucleatum, and Porphyromonas gingivalis (Fischer et al., 2012; Fischer et al., 2013). For oral bacteria, mean minimal inhibitory concentrations (MIC) range from 0.1 to $2.5 \mu \mathrm{M}$ (e.g., 0.3 to $7.8 \mu \mathrm{g} / \mathrm{ml}$ ) with the individual MIC dependent upon the specific long-chain base and oral microorganism tested.

Long-chain bases are present in the oral cavity at 1.6 to $16.6 \mu \mathrm{M}$ (e.g., 0.5 to $4.9 \mu \mathrm{g} / \mathrm{ml}$ ) concentrations (Brasser et al., 2011a). However, little is known about their cytotoxicities for oral cells at various concentrations, an important step in considering their potential as therapeutics for preventing or treating oral infections. In this study, we determined the cytotoxicities and lethal dose $50\left(\mathrm{LD}_{50}\right)$ values of long-chain bases for human oral gingival epithelial (GE) keratinocytes, oral gingival fibroblasts (GF), and dendritic cells (DC). The lipid glycerol monolaurate (GML) was used as a negative control. We also included oral squamous cell carcinoma (SCC) cells as controls, which are known to be susceptible to the cytotoxic effects of long-chain bases and their derivatives (Shirahama et al., 1997b). 


\section{Material and methods}

\subsection{Solutions, media, and long-chain bases}

$0.01 \mathrm{M}$ sodium phosphate with $0.14 \mathrm{M} \mathrm{NaCl}, \mathrm{pH} 7.2$ (PBS) was used as a diluent and as a control solution. Serum-free Lymphocyte Growth Medium 3 (LGM-3, Lonza Walkersville, Inc., Walkersville, MD) was used to cultivate GE keratinocytes, GF, and DC. Sphingosine (D-sphingosine), dihydrosphingosine (D-erythro-dihydrosphingosine), and phytosphingosine were obtained from Sigma-Aldrich (St Louis, MO). GML was obtained from LKT Laboratories (St. Paul, MN). GML is non-toxic for human and murine cells (Peterson and Schlievert, 2006). Long-chain bases were dissolved in a chloroform:methanol solution (2:1) and their purities were confirmed by thin-layer chromatography. Chloroform:methanol solutions were dispensed in glass tubes; dried under nitrogen; and resuspended and diluted in PBS to $640.0 \mu \mathrm{M}$ stock solutions.

\subsection{Cell culture}

Primary, first passage GE keratinocyte cell lines GE363, GE367, GE368, GE369, GE370, and GE371, prepared in a previous study and stored in liquid nitrogen were used in this study (Joly et al., 2005). These cells were from healthy gingival tissue samples obtained from healthy non-smoking individuals who underwent crown lengthening or canine exposure procedures. Informed consent was obtained from these individuals per a reviewed and approved protocol from the University of Iowa Institutional Review Board for the Use of Human Subjects in Research. Concentrations of GE keratinocytes were determined and adjusted to contain $1.0 \times 10^{5}$ viable cells/ml LGM-3.

Oral fibroblast primary cell lots GF365, GF367, GF368, and GF369 were isolated from the connective tissue separated from the epithelium in the above procedure. Briefly, isolated connective tissue was cut into small, 2 to $4 \mathrm{~mm}$ pieces and allowed to attach to a $60 \mathrm{~mm}$ tissue culture plate and covered with DMEM/10\% FBS with antibiotics. The connective tissue was mixed with trypsin (225.0 USP units $/ \mathrm{mg}$ ) at $37^{\circ} \mathrm{C}$, and then incubated in modified FAD media. Cells were pelleted by centrifugation for $10 \mathrm{~min}$ at $30 \times \mathrm{g}$ (IEC HN-SII, International Equipment Company, Needham Heights, MA) and suspended in modified FAD media and mixed. Cells were counted and added to six-well plates (Corning, NY) at a density of $2.5 \times 10^{5}$ cells/well in DMEM/10\% FBS with antibiotics. Concentrations of GF were determined and adjusted to contain $1.0 \times 10^{5}$ viable cells/ml LGM-3.

Primary human myeloid DC were used (StemCell Technologies, Inc., Vancouver, BC Canada). Concentrations of DC were determined and adjusted to contain $1.0 \times 10^{5}$ viable cells/ml LGM-3.

University of Michigan squamous cell carcinoma (UM-SCC) cell lines SSC-15, SCC-19, SCC-84, SCC-99, and SCC-1483 were used (Brenner et al., 2010). These cell lines were established from head and neck cancer patients who gave written informed consent to participate in studies reviewed and approved by the University of Michigan Medical School Institutional Review Board. Concentrations of UM-SCC were determined and adjusted to contain $1.0 \times 10^{5}$ viable cell/ml LGM-3. 


\subsection{Histopathologic analysis}

Immunohistochemistry (IHC) was performed to confirm the identity of isolated keratinocytes and fibroblasts. For this, GE keratinocytes and GF were fixed in 10.0\% neutral buffered formalin overnight at room temperature; pelleted by centrifugation at $400 \mathrm{~g}$ (Eppendorf 5810R centrifuge, Brinkmann Instruments, Inc., Westbury, NY); suspended in molten 2.0\% BactoAgar-2.5\% gelatin suspension as described (Jones and Calabresi, 2007); and routinely processed for microtomy. Blocks were dehydrated in 70, 80, 95, and $100 \%$ ethanol solutions; clarified (Pro-Par Clearant ${ }^{\mathrm{TM}}$, Anatech, Ltd., Battle Creek, MI); embedded in paraffin; sectioned at $4 \mu \mathrm{m}$; and stained with HE.

IHC was performed by the University of Iowa Diagnostic Laboratories (University of Iowa, Iowa City, IA) using antibodies to vimentin (Dako, Carpenteria, CA; dilution 1:900) and pancytokeratin (Dako, Carpenteria, CA). The pancytokeratin cocktail contained antibodies to AE1/AE3 (dilution 1:200), cytokeratin 7 (dilution 1:100), and cytokeratin 8/18 (dilution $1: 200)$.

\subsection{Cytotoxicity assays}

The effects of long-chain bases on cell metabolism (conversion of resazurin to resorufin), membrane permeability (uptake of propridium iodide or SYTOX-Green), release of cellular contents (LDH), cell viability by flow cytometry, and cell morphology (confocal microscopy) were all determined and used to confirm cytotoxicity in different experiments outlined below. To assess the effects of long-chain bases on cell metabolism in culture, 200 $\mu \mathrm{l}$ LGM-3 containing $2.0 \times 10^{4}$ viable cells were put into each well of a 96-well microtiter plate and allowed to attach at $37^{\circ} \mathrm{C}$ in $5 \% \mathrm{CO}_{2}$. After $2 \mathrm{~h}$, the cell culture media and nonadherent cells were removed, and LGM-3 with resazurin (Alamar Blue, Invitrogen Corp., Carlsbad, CA) containing 10.0 to $640.0 \mu \mathrm{M}$ (final concentration) long-chain base or GML was added. LGM-3 with resazurin was added to cells and served as live cell controls (LC), and LGM-3 with resazurin containing 1.0\% sodium azide was added to cells and served as killed cell controls (KC). The plates were incubated at $37^{\circ} \mathrm{C}$ with $5 \% \mathrm{CO}_{2}$ for 48 $\mathrm{h}$. The metabolic reduction of resazurin to resorufin was determined using an excitation wavelength of $544 \mathrm{~nm}$ and an emission wavelength of $590 \mathrm{~nm}$ (SpectraMax M2e MultiMode Microplate Reader, Molecular Devices, LLC, Sunnyvale, CA).

To assess the effects of long-chain bases on membrane permeability of cells in suspension, $200 \mu \mathrm{LGM}-3$ containing $2.0 \times 10^{4}$ viable cells were put into $1.5 \mathrm{ml}$ polypropylene microcentrifuge tubes; gently pelleted by centrifugation at $400 \times g$ (Eppendorf $5810 \mathrm{R}$ centrifuge, Brinkmann Instruments, Inc., Westbury, NY) for $10 \mathrm{~min}$ at $24^{\circ} \mathrm{C}$; and the supernatants were removed. Pelleted cells were suspended in LGM-3 containing 0.3 to 80.0 $\mu \mathrm{M}$ long-chain bases or GML. LGM-3 was added to cells and served as LC controls and LGM-3 containing $1.0 \%$ sodium azide was added to cells and served as $\mathrm{KC}$ controls. The tubes were incubated at $37^{\circ} \mathrm{C}$ with $5 \% \mathrm{CO}_{2}$. At $16 \mathrm{~h}$, the cells were gently pelleted by centrifugation and the supernatants were removed. $100 \mu$ of LGM-3 plus $10 \mu$ of propidium iodide $(0.5 \mathrm{mg} / \mathrm{ml}$, Sigma-Aldrich, St. Louis, MO) were then added to the cell pellet and gently mixed. A $10 \mu \mathrm{l}$ aliquot of cell suspension was removed and placed in a 
hemocytometer for the determination of total cell count and viable cell count by fluorescence microscopy.

A key signature for necrotic cells is the permeabilization of plasma membrane, which can be quantified in tissue culture measuring the release of lactate dehydrogenase (Chan et al., 2013). In this study, lactate dehydrogenase (LDH) was determined in tissue culture supernatants using the CytoTox 96 Non-radioactive Cytotoxicity Assay (Promega Corp., Madison, WI) and read at $490 \mathrm{~nm}$ in the spectrophotometer (SpectraMax M2e Multi-Mode Microplate Reader, Molecular Devices, LLC, Sunnyvale, CA).

To assess the effects of long-chain bases on cell viability using flow cytometry, $600 \mu \mathrm{l}$ LGM-3 containing 1.4 to $2.4 \times 10^{5}$ viable DC/ml were put into $12 \times 75 \mathrm{~mm}$ round bottom polypropylene tubes and treated first, with $500 \mathrm{nM} \mathrm{C}_{12}$-Resazurin and $10 \mathrm{nM} \mathrm{SYTOX-}$ Green (LIVE/DEAD® Cell Vitality Assay Kit, Molecular Probes) and second, with 5.0 or $80.0 \mu \mathrm{M}$ long-chain base or GML. At 0, 20, 40, and $60 \mathrm{~min}$, the cells were examined using a LSR II Flow Cytometer (BD Biosciences, San Jose, CA) using excitation wavelengths of 488 (SYTOX-Green) and $561 \mathrm{~nm}$ (resorufin) and emission wavelengths of 530 and $585 \mathrm{~nm}$, respectively. Compensation controls were utilized to adjust for spectral overlap across dyes. Additional controls included long-chain bases alone in media with and without added dyes to assess potential autofluorescence and the potential affinity of either dye for long-chain bases or GML; DC in LGM-3; DC in LGM-3 heated at $56^{\circ} \mathrm{C}$ for $10 \mathrm{~min}$, DC in LGM-3 containing $2 \mathrm{mM}$ hydrogen peroxide; or DC in LGM-3 containing 1.0\% sodium azide. Flow cytometric data was analyzed using FlowJo software (Tree Star, Inc., Ashland, OR) and all experiments were completed in triplicate.

To assess the effects of long-chain bases on cell morphology, $600 \mu \mathrm{l}$ of LGM-3 containing $1.0 \times 10^{5}$ viable $\mathrm{DC} / \mathrm{ml}$ was put into each of four chambers of Lab-Tek $\mathrm{TM}_{\mathrm{TM}}$ chamber slides (Thermo Scientific, Rockford, IL) and incubated at $37^{\circ} \mathrm{C}$ with $5 \% \mathrm{CO}_{2}$ for $2 \mathrm{~h}$ to allow the cells to attach. DC were first treated with $500 \mathrm{nM} \mathrm{C}_{12}$-Resazurin and $10 \mathrm{nM}$ SYTOX-Green (LIVE/DEAD® Cell Vitality Assay Kit, Molecular Probes, Eugene, OR) and then with 5.0 or $80.0 \mu \mathrm{M}$ long-chain base or GML. At $0,20,40$, and $60 \mathrm{~min}$, the slides were examined using a Zeiss 710 LSM confocal microscope (Carl Zeiss Micro Imaging GmbH, Jena, Germany).

\subsection{Statistical analysis}

Percent cytotoxicity was defined as the median fluorescence intensity (MFI) of resazurin in cell culture media of cells treated with dilutions of long-chain bases/MFI of resazurin in cell culture media of untreated cells $\times 100$. The lethal dose $50\left(\mathrm{LD}_{50}\right)$ was determined from the dose response curve where the 50 percent cytotoxicity intercepts with the long-chain base concentration on the $\mathrm{x}$-axis. A $\log 10$-transformation was applied to the long-chain base $\mathrm{LD}_{50}$ concentrations for GE keratinocytes, GF, DC, and SCC cells. The log transformation attenuates the positive skew in the distributions of the $\mathrm{LD}_{50}$ concentrations and makes the normality assumption more defensible. For analysis, the long-chain base $\mathrm{LD}_{50}$ concentrations were first transformed by adding $1 \mathrm{uM}$ to each $\mathrm{LD}_{50}$ value. In those instances where the $\mathrm{LD}_{50}$ was $>640.0 \mu \mathrm{M}$ the value used for the $\log 10$-transformation was $641.0 \mu \mathrm{M}$. One-way fixed-effects ANOVA models were then fit to the log-transformed concentrations. 
The factor levels consisted of the dilution levels for each long-chain base at $48 \mathrm{~h}$. Pairwise group comparisons were conducted using the method of Tukey's Honest Significant Differences. A 0.05 level was used to determine statistically significant differences. All analyses were conducted using JMP (Version 10.0, SAS, Cary, NC).

\section{Results}

\subsection{Histopathologic analysis}

All GE keratinocytes (e.g., GE363, GE368, GE369, GE370, and GE371) expressed AE1/ AE3, cytokeratin 7, and/or cytokeratin 8/18 and did not express vimentin confirming that these cells were keratinocytes (see Fig. 1a-c in (Mehalick et al., 2015)). Likewise, GF368 and GF369 preparations did not express AE1/AE3, cytokeratin 7, and/or cytokeratin 8/18 yet did express vimentin confirming that these cells were of mesenchymal origin (see Fig. 1d-f in (Mehalick et al., 2015)).

\subsection{GE keratinocytes, GF, and SCC cell cytotoxicity}

The effects of long-chain bases on cell metabolism (conversion of resazurin to resorufin) were first determined and GE keratinocytes were more resistant to the three long-chain bases while GF and SCC were more susceptible (Fig. 1, Table 1). GE367, GE368, and GE370 were highly resistant to the cytotoxicity of sphingosine (> 640.0 $\mu \mathrm{M})$, dihydrosphingosine (range 256.0 to $>640.0 \mu \mathrm{M}$ ), and phytosphingosine (range 122.7 to $>640.0 \mu \mathrm{M}$ ). In contrast, GE363, GE369, and GE371 were more susceptible to the cytotoxicity of sphingosine (range 17.2 to $60.7 \mu \mathrm{M}$ ), dihydrosphingosine (range 17.1 to $27.3 \mu \mathrm{M}$ ), and phytosphingosine (range $<10.0$ to $19.4 \mu \mathrm{M}$ ). A representative set of graphs for GE368 are shown in Fig. 2.

GF were susceptible to the cytotoxicity of long-chain bases (Fig. 3, Table 1). GF367, GE368, and GE369 were highly susceptible to the cytotoxicity of sphingosine (range <10.0 to $20.4 \mu \mathrm{M}$ ), dihydrosphingosine (range $<10.0$ to $21.4 \mu \mathrm{M}$ ), and phytosphingosine (range $<10.0$ to $17.4 \mu \mathrm{M}$ ). In contrast, GF365 was resistant to the cytotoxicity of sphingosine (> $640.0 \mu \mathrm{M})$, dihydrosphingosine (> $640.0 \mu \mathrm{M})$, and phytosphingosine $(>640.0 \mu \mathrm{M})$. Interestingly, GE keratinocytes and GF cultured from two individuals had differing susceptibilities to the cytotoxicity of long-chain bases. For example, GE367 and GE368 were more resistant to the cytotoxicity of sphingosine (>640.0 $\mu \mathrm{M})$, dihydrosphingosine (range 256.0 to $>640.0 \mu \mathrm{M}$ ), and phytosphingosine (range 122.7 to $>640.0 \mu \mathrm{M}$ ) while GF367 and GF368 were more susceptible to the cytotoxicity of sphingosine $(<10.0 \mu \mathrm{M})$, dihydrosphingosine $(<10.0 \mu \mathrm{M})$, and phytosphingosine (range 4.2 to $18.0 \mu \mathrm{M})$. In contrast, GE369 and GF369 cultured from the same individual had very similar susceptibilities to the cytotoxicity of long-chain bases.

SCC cells, used as a control, were the most susceptible to the cytotoxicity of long-chain bases (Fig. 4, Table 1). All five of the SCC cell lines (e.g., SCC15, SCC19, SCC84, SCC99, and SCC1483) were susceptible to sphingosine (range $<10.0$ to $32.3 \mu \mathrm{M}$ ), dihydrosphingosine (range 5.8 to $28.2 \mu \mathrm{M}$ ), and phytosphingosine (range 7.3 to $17.2 \mu \mathrm{M}$ ). 


\subsection{DC cytotoxicity}

The effects of long-chain bases on cell metabolism (conversion of resazurin to resorufin) were also determined. Overall, DC were susceptible to long-chain bases however, there was heterogeneity among the cell lines in their response to sphingosine (cytotoxicity range 16.8 to $287.1 \mu \mathrm{M}$; mean $\mathrm{LD}_{50} 32.8 \mu \mathrm{M} \pm 3.1 \mu \mathrm{M}$ std err), dihydrosphingosine (cytotoxicity range 13.9 to $58.9 \mu \mathrm{M}$; mean $\mathrm{LD}_{50} 24.5 \mu \mathrm{M} \pm 1.3 \mu \mathrm{M}$ std err), phytosphingosine (cytotoxicity range 8.1 to $>40.0 \mu \mathrm{M}$; mean $\mathrm{LD}_{50} 15.2 \mu \mathrm{M} \pm 0.3 \mu \mathrm{M}$ std err), and GML (cytotoxicity range 108.8 to $>160.0 \mu \mathrm{M}$; mean $\mathrm{LD}_{50}>80.0 \mu \mathrm{M}$ (Fig. 5, see Fig. 2 in (Mehalick et al., 2015)). Therefore the cytotoxicity of physiologic $(5.0 \mu \mathrm{M})$ and high $(80.0 \mu \mathrm{M})$ concentrations of sphingosine, dihydrosphingosine, phytosphingosine, and GML were studied in depth at 0.0 to 60.0 min with flow cytometry and confocal microscopy.

In flow cytometry, DC treated with 5.0 and $80.0 \mu \mathrm{M}$ long-chain bases and GML had both concentration-dependent and time-dependent shifts in the numbers of cells with SYTOXGreen stained nuclei (Fig. 6a-h, see Fig. 3 in (Mehalick et al., 2015)). 5.0 $\mu \mathrm{M}$ sphingosine and GML were not cytotoxic and 5.0 $\mu \mathrm{M}$ dihydrosphingosine and phytosphingosine were only mildly cytotoxic whereas $80.0 \mu \mathrm{M}$ sphingosine, dihydrosphingosine, and phytosphingosine were cytotoxic. $80.0 \mu \mathrm{M}$ GML concentrations were not cytotoxic. The majority of DC were dead within 20 to $40 \mathrm{~min}$ of exposure (Fig. $\mathbf{6 d}, \mathbf{f}, \mathbf{h}$ ).

In confocal microscopy, untreated control DC appeared healthy, had normal DC processes, had $\mathrm{C}_{12}$-resazurin stained cytoplasm, and had no SYTOX-Green stained nuclei (data not shown). Killed control DC appeared rounded, had $\mathrm{C}_{12}$-resazurin stained cytoplasm, and had SYTOX-Green stained nuclei (data not shown). DC treated with 5.0 and $80.0 \mu \mathrm{M}$ long-chain bases and GML had both concentration-dependent and time-dependent changes in cell morphology and nuclear staining. DC exposed to $5.0 \mu \mathrm{M}$ long-chain bases were alive after one hour of treatment although many cells reacted to low long-chain base concentrations by withdrawing their dendritic processes. For example, DC treated with $5.0 \mu \mathrm{M}$ phytosphingosine became rounded and a few cells detached, but most cells were alive one hour after treatment (Fig. 6a, c, e, g). DC treated with $5.0 \mu \mathrm{M}$ of GML remained unaffected and were similar to untreated controls (data not shown).

DC exposed to $80.0 \mu \mathrm{M}$ long-chain bases rounded, quickly withdrawing their dendritic processes, detached from the slide surface, and had SYTOX-Green stained nuclei, indicating death of the cells. At 20 min many cells resembled the killed controls that were rounded, detached, with SYTOX-Green stained nuclei. At $40 \mathrm{~min}$ and $60 \mathrm{~min}$, few cells remained attached to the slide and most of the remaining cells' nuclei were SYTOX-Green stained. For example, DC treated with $80.0 \mu \mathrm{M}$ phytosphingosine became rounded and quickly withdrew their dendritic processes (Fig. 6b). Cells quickly detached from the slide surface and had SYTOX-Green stained nuclei, indicating death of the cells (Fig. 6d, f, h). In addition, many cells appeared misshapen with adjacent cellular debris. DC exposed to 80.0 $\mu \mathrm{M}$ GML also rounded, quickly withdrawing their dendritic processes; however, after 60 min incubation, most cells remained alive and attached to the slide (data not shown). 


\section{Discussion}

Long-chain bases are present in saliva at 1.6 to $16.6 \mu \mathrm{M}$ (e.g., 0.5 to $4.9 \mu \mathrm{g} / \mathrm{ml}$ )

concentrations (Brasser et al., 2011a). They also have potent antimicrobial activity against $S$. sanguinis, S. mitis, F. nucleatum, and P. gingivalis at these same ranges (Fischer et al., 2013). We believe they may have potential to prevent or treat oral microbial infections. As part of this process, we need to know the cytotoxicities and $\mathrm{LD}_{50}$ concentrations of longchain bases for oral cells. This information would clearly help in establishing prophylactic or therapeutic doses. In this report, we show that sphingosine, dihydrosphingosine, and phytosphingosine do have some cytotoxicities for GE keratinocytes, GF and DC, but these concentrations are considerably higher than the MIC concentrations reported for oral microorganisms.

In this study GE keratinocytes from some cell lines were very resistant, cytotoxicities were > $640.0 \mu \mathrm{M}$ (out of the range of the assays). However, because long-chain bases do not go into solution easily and at $640.0 \mu \mathrm{M}$ begin to precipitate on the bottom of the microtiter plate, our values of cytotoxicities may be underestimated. Other GE keratinocyte cell lines were moderately resistant and cytotoxicities were well within the upper limits of the cytotoxicity assay. GF and DC were more susceptible to the long-chain bases.

The cytotoxicity of long-chain bases is not unusual and multiple studies recently have assessed long-chain base cytotoxicity on a variety of cell types primarily to assess their potential as anti-cancer therapies. Neoplastic cells are known to be particularly susceptible. For example, in murine cell lines, sphingosine, dihydrosphingosine, and C6-ceramide are cytotoxic for murine $\mathrm{P} 388$ leukemia cells $\left(\mathrm{EC}_{50}, 2.5\right.$ to $\left.5.0 \mu \mathrm{M}\right)$ and murine multi-drug resistant P388 leukemia cells $\left(\mathrm{EC}_{50}, 5.0\right.$ to $\left.10.0 \mu \mathrm{M}\right)$ (Klostergaard et al., 1998).

Phytosphingosine and phytosphingosine derivatives are cytotoxic to murine melanoma B16 cells (10.0 to $50.0 \mu \mathrm{M} ; \mathrm{IC}_{50}, 15 \mu \mathrm{M}$ ) (Rives et al., 2011). In human cells and cell lines, sphingosine is cytotoxic for DLD-1 cells ( $\mathrm{LD}_{50}, 26.7 \mu \mathrm{M}$ ) (Sugawara et al., 2006), WiDr cells $\left(\mathrm{LD}_{50}, 22.9 \mu \mathrm{M}\right)$ (Sugawara et al., 2006), Caco-2 colon cancer cells $\left(\mathrm{LD}_{50}, 24.2 \mathrm{uM}\right)$ (Sugawara et al., 2006) and HL-60 human promyelocytic leukemia cells (10 $\mu \mathrm{M})$ (Johnson et al., 2004). 4,8-sphingadienine is cytotoxic for immortalized human umbilical vein endothelial cells (>20.0 $\mu \mathrm{M}$ ) (Rozema et al., 2012). In the present study SCC15, SCC19, SCC84, SCC99, and SCC1483 used as controls, were susceptible to sphingosine (range $<10.0$ to $32.3 \mu \mathrm{M}$ ), dihydrosphingosine (range 5.8 to $28.2 \mu \mathrm{M}$ ), and phytosphingosine (range 7.3 to $17.2 \mu \mathrm{M}$ ) suggesting a potential therapeutic use for long-chain bases against oral squamous cell carcinoma.

The underlying mechanisms of cell death induced by long-chain bases are not well known. Some studies suggest that long-chain bases mediate cell death by apoptosis. For example, apoptosis was induced by phorbol ester in human promyelocytic leukemia HL-60 cells (Johnson et al., 2004; Ohta et al., 1995), a human prostatic carcinoma cell line DU-145 (Shirahama et al., 1997a), and human epidermoid carcinoma KB-3-1 cells (Shirahama et al., 1997b). However, long-chain bases may mediate cell death by necrosis. A key signature for necrotic cells is the permeabilization of plasma membrane, which can be quantified in tissue culture measuring the release of LDH (Chan et al., 2013). In this study, (LDH) was released 
at higher concentrations of long-chain bases (see Fig. 2 in (Mehalick et al., 2015)). The exact mechanism of cell death will have to be determined in future studies solely focusing on staining of markers on the treated cell surface with FITC-Annexin-V/propidium iodide (apoptosis); assessing cell death pathway markers in treated cells such as caspase-3, BcL-2, and calpain 2 (apoptosis); and determining extracellular markers of treated cells such as calcium change (necrosis cell death) and LDH release (necrosis cell death).

Long chain bases also act on protein kinase C (PKC) with inhibition of the MAPK cascade in some solid tumor cells (Sakakura et al., 1997) and downstream loss of extracellular signal-regulated kinase (ERK)1/ERK2 (Johnson et al., 2004).

In summary, the $\mathrm{LD}_{50}$ of long-chain bases for GE keratinocytes, $\mathrm{GF}$, and DC were considerably higher than their MIC for oral pathogens. The underlying reasons for the differences in cytotoxicities are not well known. The differences of long chain base cytotoxicity in these cells may be in part explained by the differences in the membrane composition of these cells. The lipid composition in the cell membranes of DC (Laulagnier et al., 2004) and keratinocytes (Ponec et al., 1988) are reported to be different. Regardless, the relative cytotoxicity correlated with the anatomic location of the cells coming in contact with long-chain bases. For example, GE keratinocytes on the surface of the oral mucosa would be expected to be more resistant to long-chain bases present in saliva than the underlying GF and DC, which were more susceptible. Overall, long-chain bases have potent antimicrobial activity and exhibit low levels of cytotoxicity for GE keratinocytes, GF, DC, and SCC cells at concentrations well above cited physiologic and antimicrobial ranges. They could be considered as therapeutic agents for the treatment of oral microbial infections, where higher than physiologic concentrations maybe needed to kill oral pathogens.

\section{Acknowledgements}

The data presented herein were obtained at the Flow Cytometry Facility, which is a Carver College of Medicine / Holden Comprehensive Cancer Center core research facility at the University of Iowa. The Facility is funded through user fees and the generous financial support of the Carver College of Medicine, Holden Comprehensive Cancer Center, and Iowa City Veteran's Administration Medical Center.

\section{Abbreviations}

$\begin{array}{ll}\text { GE } & \text { human oral gingival epithelial keratinocytes } \\ \text { GF } & \text { oral gingival fibroblasts } \\ \text { DC } & \text { dendritic cells } \\ \text { GML } & \text { glycerol monolaurate } \\ \text { SCC } & \text { oral squamous cell carcinoma cells } \\ \text { LDH } & \text { lactate dehydrogenase } \\ \text { MFI } & \text { median fluorescence intensity } \\ \text { MIC } & \text { minimal inhibitory concentrations }\end{array}$




\section{References}

Bibel DJ, Aly R, Shinefield HR. Antimicrobial activity of sphingosines. J. Invest. Dermatol. 1992; 98:269-273. [PubMed: 1545135]

Brasser, A.; Barwacz, C.; Dawson, D.; Brogden, K.; Drake, D.; Wertz, P. Composition of human salivary lipids in human saliva. 88th General Session AADR/CADR Annual Meeting; Washington, DC. 2010.

Brasser, AJ.; Barwacz, CA.; Bratt, CL.; Dawson, DV.; Brogden, KA.; Drake, DR.; Wertz, PW. Free sphingosine in human saliva. 89th General Session IADR/AADR/CADR Annual Meeting; San Diego. 2011a.

Brasser AJ, Barwacz CA, Dawson DV, Brogden KA, Drake DR, Wertz PW. Presence of wax esters and squalene in human saliva. Arch Oral Biol. 2011b; 56:588-591. [PubMed: 21247555]

Brenner JC, Graham MP, Kumar B, Saunders LM, Kupfer R, Lyons RH, Bradford CR, Carey TE. Genotyping of 73 UM-SCC head and neck squamous cell carcinoma cell lines. Head Neck. 2010; 32:417-426. [PubMed: 19760794]

Chan FK, Moriwaki K, De Rosa MJ. Detection of necrosis by release of lactate dehydrogenase activity. Methods Mol Biol. 2013; 979:65-70. [PubMed: 23397389]

Defago MD, Valentich MA, Actis AB. Lipid characterization of human saliva. J. Calif. Dent. Assoc. 2011; 39:874-880. [PubMed: 22409138]

Fischer CL, Drake DR, Dawson DV, Blanchette DR, Brogden KA, Wertz PW. Antibacterial activity of sphingoid bases and fatty acids against Gram-positive and Gram-negative bacteria. Antimicrob Agents Chemother. 2012; 56:1157-1161. [PubMed: 22155833]

Fischer CL, Walters KS, Drake DR, Dawson DV, Blanchette DR, Brogden KA, Wertz PW. Oral mucosal lipids are antibacterial against Porphyromonas gingivalis, induce ultrastructural damage, and alter bacterial lipid and protein compositions. Int J Oral Sci. 2013; 5:130-140. [PubMed: 23867843]

Johnson CR, Chun J, Bittman R, Jarvis WD. Intrinsic cytotoxicity and chemomodulatory actions of novel phenethylisothiocyanate sphingoid base derivatives in HL-60 human promyelocytic leukemia cells. J. Pharmacol. Exp. Ther. 2004; 309:452-461. [PubMed: 14724218]

Joly S, Organ CC, Johnson GK, McCray PB Jr. Guthmiller JM. Correlation between beta-defensin expression and induction profiles in gingival keratinocytes. Mol Immunol. 2005; 42:1073-1084. [PubMed: 15829297]

Jones MV, Calabresi PA. Agar-gelatin for embedding tissues prior to paraffin processing. Biotechniques. 2007; 42:569-570. [PubMed: 17515193]

Kensche A, Reich M, Kummerer K, Hannig M, Hannig C. Lipids in preventive dentistry. Clin. Oral Investig. 2013; 17:669-685.

Klostergaard J, Auzenne E, Leroux E. Characterization of cytotoxicity induced by sphingolipids in multidrug-resistant leukemia cells. Leuk. Res. 1998; 22:1049-1056. [PubMed: 9783808]

Larsson B, Olivecrona G, Ericson T. Lipids in human saliva. Arch Oral Biol. 1996; 41:105-110. [PubMed: 8833598]

Laulagnier K, Motta C, Hamdi S, Roy S, Fauvelle F, Pageaux JF, Kobayashi T, Salles JP, Perret B, Bonnerot C, Record M. Mast cell- and dendritic cell-derived exosomes display a specific lipid composition and an unusual membrane organization. Biochem J. 2004; 380:161-171. [PubMed: 14965343]

Mehalick LA, Poulsen C, Fischer CL, Lanzel EA, Bates AM, Walters KS, Cavanaugh JE, Guthmiller JM, Johnson GK, Wertz PW, Brogden KA. Differential cytotoxicity of long-chain bases for human oral gingival epithelial keratinocytes, oral fibroblasts, and dendritic cells. 2015 Data in Brief "in press".

Ohta H, Sweeney EA, Masamune A, Yatomi Y, Hakomori S, Igarashi Y. Induction of apoptosis by sphingosine in human leukemic HL-60 cells: a possible endogenous modulator of apoptotic DNA fragmentation occurring during phorbol ester-induced differentiation. Cancer Res. 1995; 55:691697. [PubMed: 7834642]

Palmerini CA, Saccardi C, Ferracci F, Arienti S. Lipid patterns in the saliva of smoking young adults. Hum. Exp. Toxicol. 2011; 30:1482-1488. [PubMed: 21300688] 
Peterson ML, Schlievert PM. Glycerol monolaurate inhibits the effects of Gram-positive select agents on eukaryotic cells. Biochemistry (Mosc). 2006; 45:2387-2397.

Ponec M, Weerheim A, Kempenaar J, Mommaas AM, Nugteren DH. Lipid composition of cultured human keratinocytes in relation to their differentiation. J Lipid Res. 1988; 29:949-961. [PubMed: 2457643]

Rives A, Baudoin-Dehoux C, Saffon N, Andrieu-Abadie N, Genisson Y. Asymmetric synthesis and cytotoxic activity of isomeric phytosphingosine derivatives. Org Biomol Chem. 2011; 9:81638170. [PubMed: 21986639]

Rozema E, Binder M, Bulusu M, Bochkov V, Krupitza G, Kopp B. Effects on inflammatory responses by the sphingoid base 4,8-sphingadienine. Int. J. Mol. Med. 2012; 30:703-707. [PubMed: 22710663]

Sakakura C, Sweeney E, Shirahama T, Ruan F, Solca F, Kohno M, Hakomori S, Fischer E, Igarashi Y. Inhibition of MAP kinase by sphingosine and its methylated derivative, N,N-dimethylsphingosine. Int. J. Oncol. 1997; 11:31-39. [PubMed: 21528177]

Shirahama T, Sakakura C, Sweeney EA, Ozawa M, Takemoto M, Nishiyama K, Ohi Y, Igarashi Y. Sphingosine induces apoptosis in androgen-independent human prostatic carcinoma DU-145 cells by suppression of bcl-X(L) gene expression. FEBS Lett. 1997a; 407:97-100. [PubMed: 9141489]

Shirahama T, Sweeney EA, Sakakura C, Singhal AK, Nishiyama K, Akiyama S, Hakomori S, Igarashi $\mathrm{Y}$. In vitro and in vivo induction of apoptosis by sphingosine and $\mathrm{N}, \mathrm{N}$-dimethylsphingosine in human epidermoid carcinoma KB-3-1 and its multidrug-resistant cells. Clin. Cancer Res. 1997b; 3:257-264. [PubMed: 9815681]

Sugawara T, Zaima N, Yamamoto A, Sakai S, Noguchi R, Hirata T. Isolation of sphingoid bases of sea cucumber cerebrosides and their cytotoxicity against human colon cancer cells. Biosci., Biotechnol., Biochem. 2006; 70:2906-2912. [PubMed: 17151482] 


\section{Highlights}

Long-chain bases sphingosine and dihydrosphingosine are in saliva and have antimicrobial activity against oral pathogens.

We determined the toxicity of sphingosine, dihydrosphingosine, and phytosphingosine for GE keratinocytes, GF, DC, and SCC cells.

The $\mathrm{LD}_{50}$ of long-chain bases for GE keratinocytes, GF, SCC cells, and DC were considerably higher than their MIC for oral pathogens.

This finding is important in pursuing the future potential of long-chain bases in treating periodontal and oral infections. 


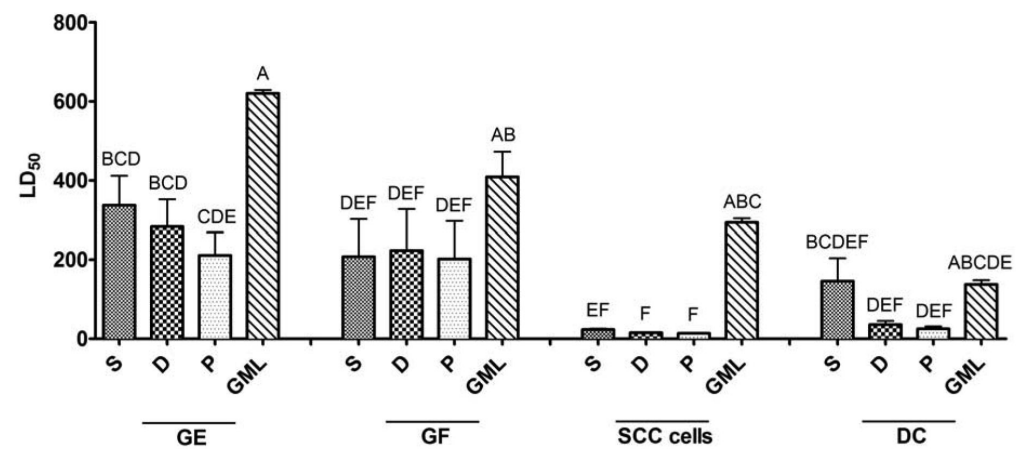

Fig. 1.

Long-chain bases affect cell metabolism (conversion of resazurin to resorufin) and there are differing mean lethal dose $50\left(\mathrm{LD}_{50}\right)$ values of sphingosine $(\mathrm{S})$, dihydrosphingosine (D), phytosphingosine (P), and glycerol monolaurate (GML) for oral gingival epithelial (GE) keratinocytes, oral fibroblasts (GF), dendritic cells (DC), and oral squamous cell carcinoma (SCC) cells. The effects of long-chain bases on cell metabolism (conversion of resazurin to resorufin) were first determined. Percent cytotoxicity was then defined as the median fluorescence intensity (MFI) of resazurin in cell culture media of cells treated with dilutions of long-chain bases/MFI of resazurin in cell culture media of untreated cells $\times 100$, and the $\mathrm{LD}_{50}$ values were determined from the dose response curve where the 50 percent cytotoxicity intercepts with the long-chain base concentration on the $\mathrm{x}$-axis. Values not connected by the same letter are significantly different. The statistical analysis of the data in this graph can be found in Table 1. 

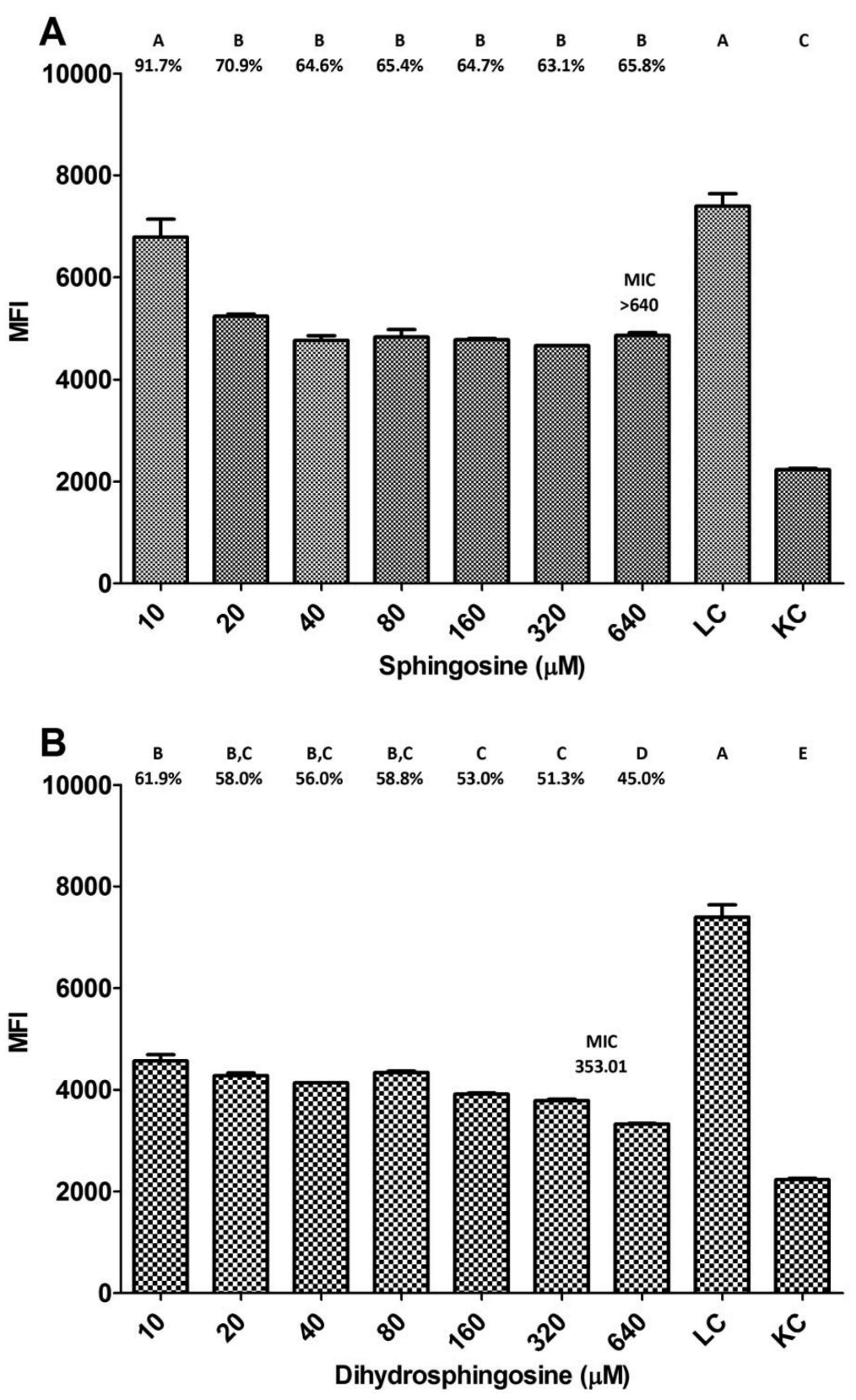

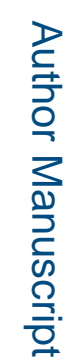



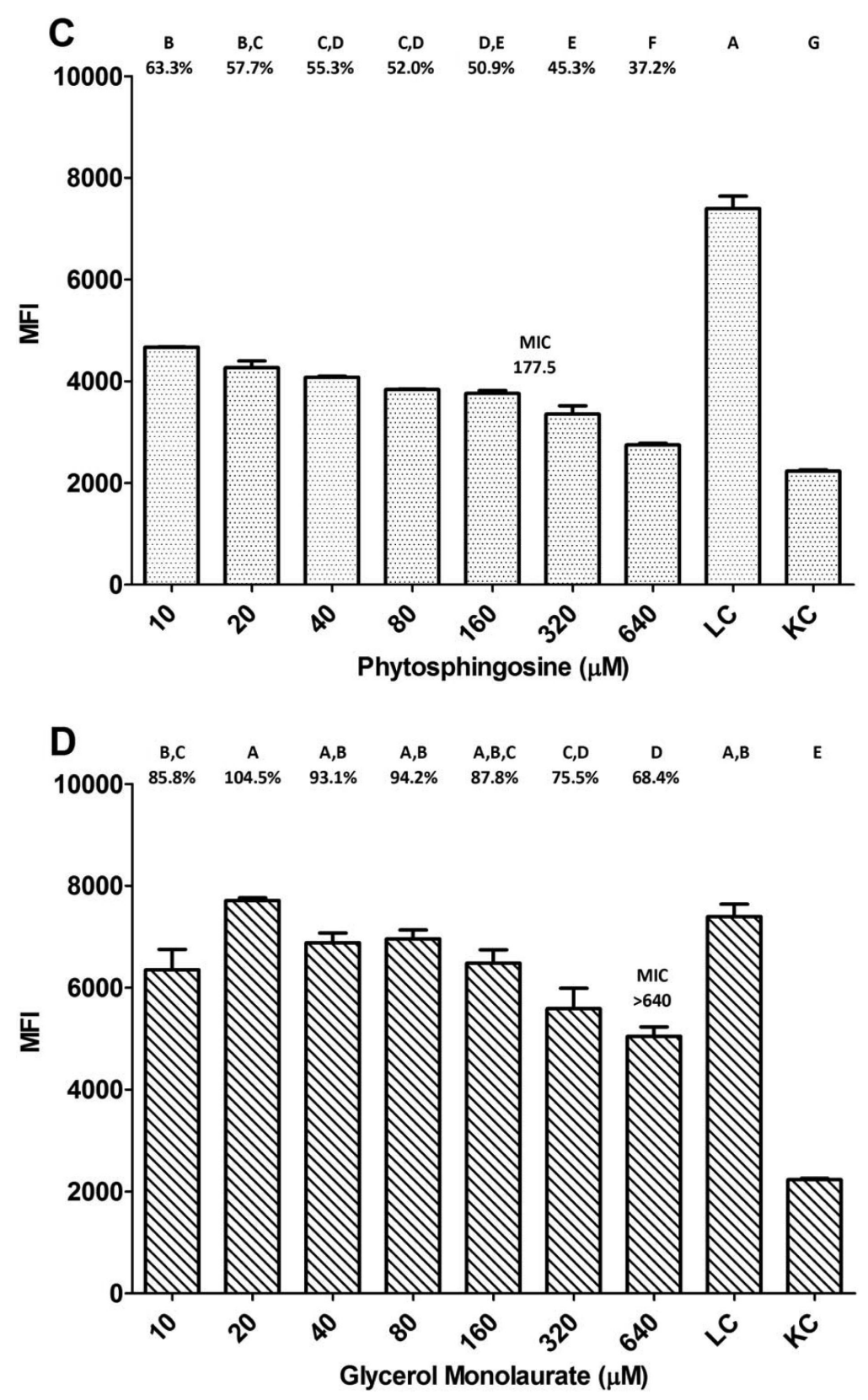

Fig. 2.

Long-chain bases and glycerol monolaurate affect the cell metabolism (conversion of resazurin to resorufin) of primary human oral gingival epithelial (GE) keratinocytes (GE368). The graphs below show the median fluorescence intensity (MFI) of resorufin in GE368 cell culture after $48 \mathrm{~h}$ of exposure to 10.0 to $640.0 \mu \mathrm{M}$ sphingosine (A), dihydrosphingosine (B), phytosphingosine (C), and glycerol monolaurate (D). LGM-3 with resazurin was added to untreated cells and served as live cell controls (LC). LGM-3 with resazurin containing $1 \%$ sodium azide was added to cells and served as killed cell controls (KC). MFI values not connected by the same letter are significantly different. Cytotoxicity $(\%)=$ the MFI of resazurin in cell culture media of cells treated with dilutions of long-chain 
bases/MFI of resazurin in cell culture media of untreated cells $\times 100 . \mathrm{LD}_{50}=$ value where the 50 percent cytotoxicity intercepts with the long-chain base concentration on the $\mathrm{x}$-axis. 

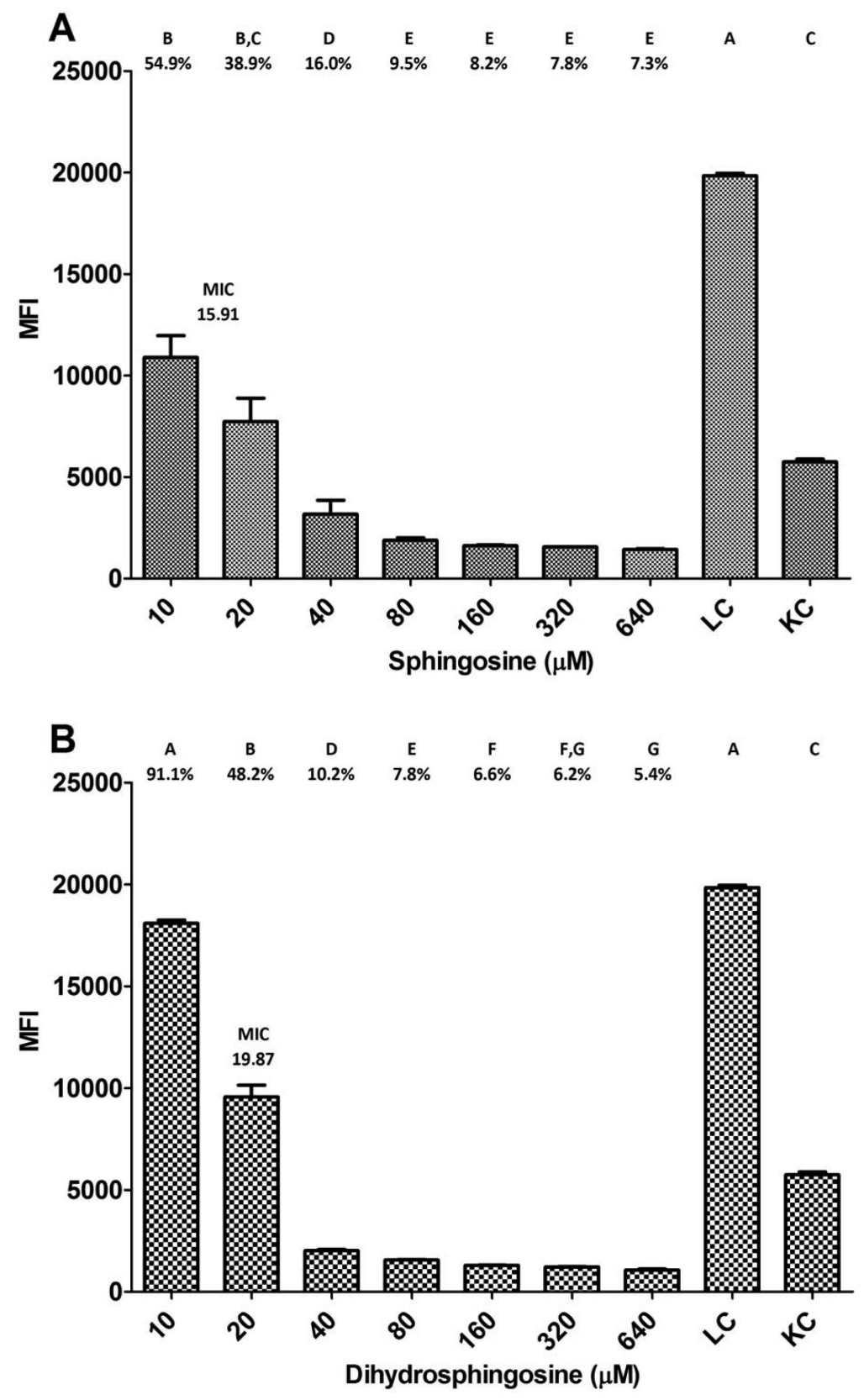

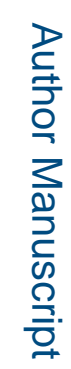



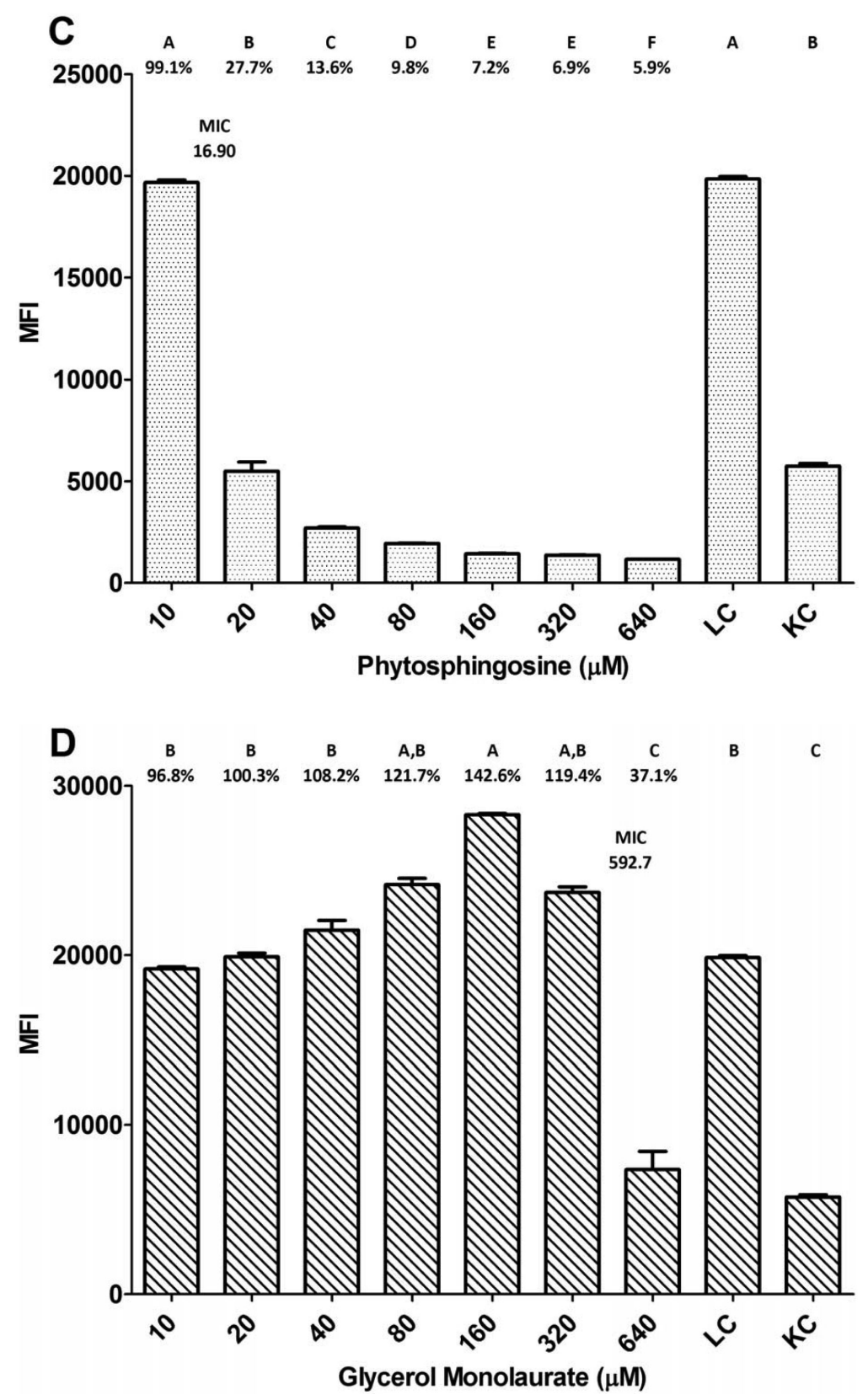

Fig. 3.

Long-chain bases and glycerol monolaurate affect the cell metabolism (conversion of resazurin to resorufin) of a primary human oral gingival fibroblast cell culture (GF369). The graphs below show the median fluorescence intensity (MFI) of resorufin in GF369 cell culture after $48 \mathrm{~h}$ of exposure to 10.0 to $640.0 \mu \mathrm{M}$ sphingosine (A), dihydrosphingosine (B), phytosphingosine (C), and glycerol monolaurate (D). LGM-3 with resazurin was added to untreated cells and served as live cell controls (LC). LGM-3 with resazurin containing 1\% sodium azide was added to cells and served as killed cell controls (KC). MFI values not connected by the same letter are significantly different. Cytotoxicity $(\%)=$ the MFI of resazurin in cell culture media of cells treated with dilutions of long-chain bases/MFI of 
resazurin in cell culture media of untreated cells $\times 100 . \mathrm{LD}_{50}=$ value where the 50 percent cytotoxicity intercepts with the long-chain base concentration on the $\mathrm{x}$-axis. 

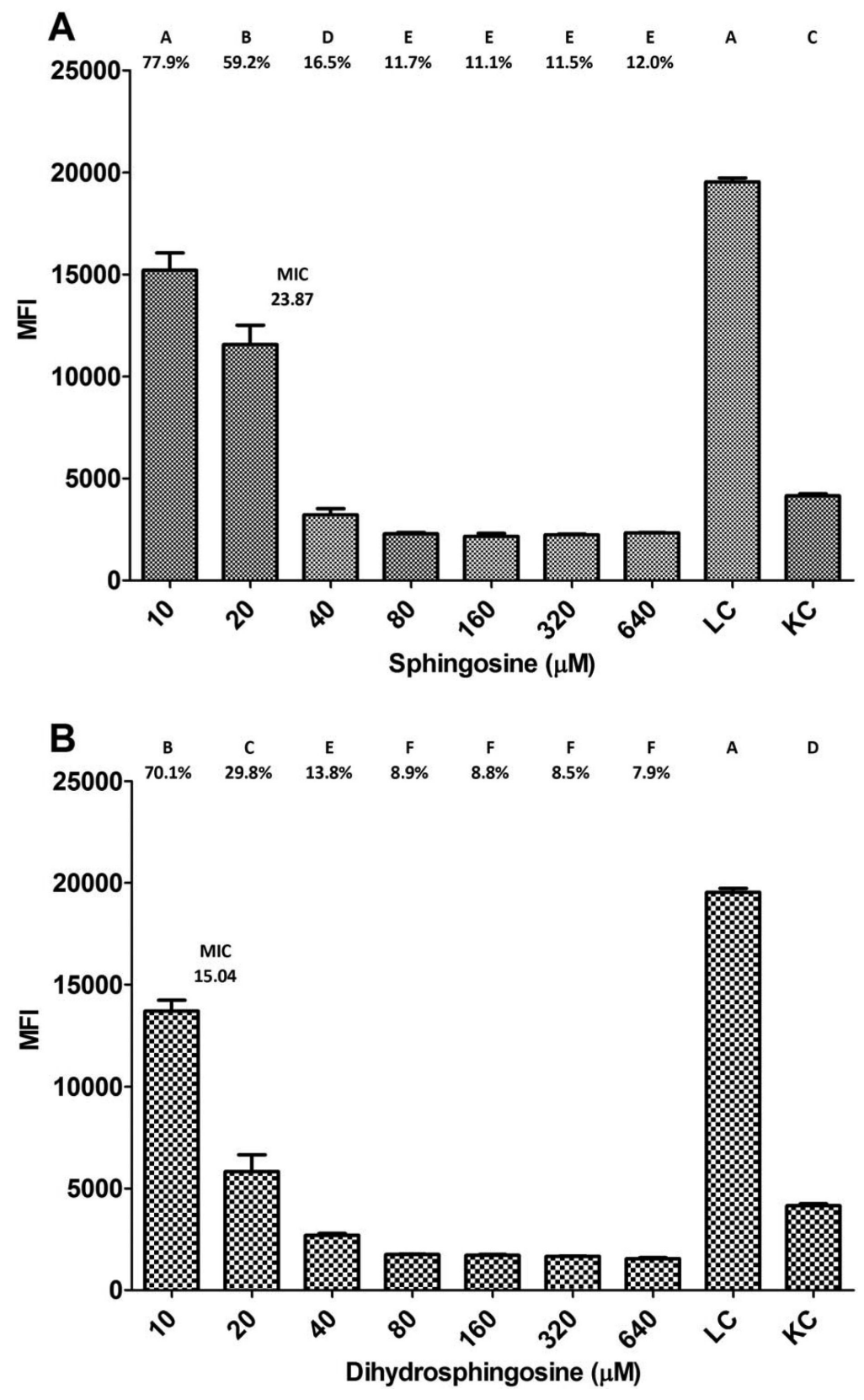

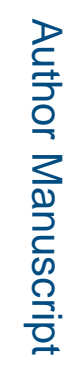



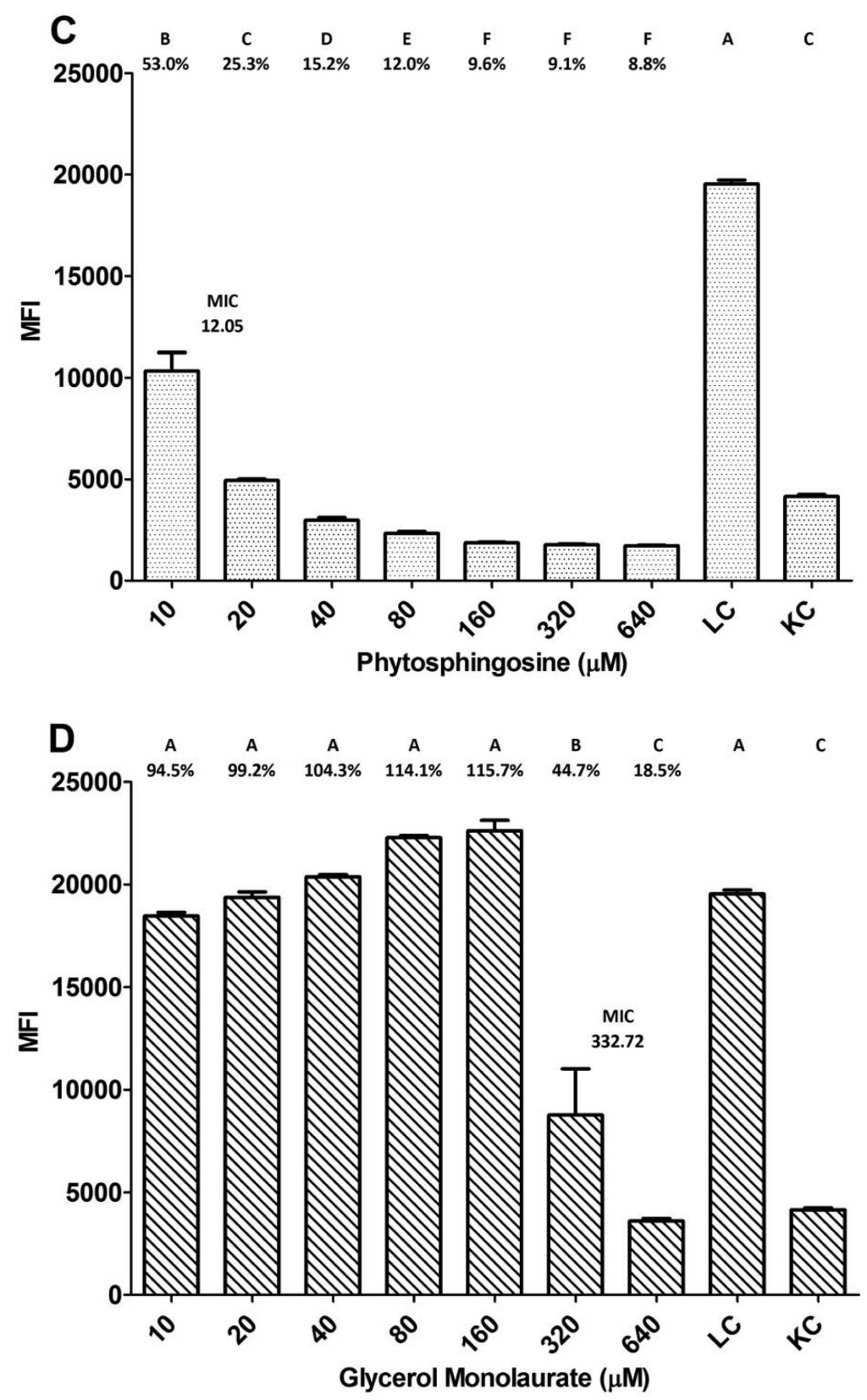

Fig. 4.

Long-chain bases and glycerol monolaurate affect the cell metabolism (conversion of resazurin to resorufin) of a squamous cell carcinoma cell culture SCC15. The graphs below show the median fluorescence intensity (MFI) of resorufin in SCC15 cell culture after $48 \mathrm{~h}$ of exposure to 10.0 to $640.0 \mu \mathrm{M}$ sphingosine (A), dihydrosphingosine (B), phytosphingosine (C), and glycerol monolaurate (D). LGM-3 with resazurin was added to untreated cells and served as live cell controls (LC). LGM-3 with resazurin containing $1 \%$ sodium azide was added to cells and served as killed cell controls (KC). MFI values not connected by the same letter are significantly different. Cytotoxicity $(\%)=$ the MFI of resazurin in cell culture media of cells treated with dilutions of long-chain bases/MFI of resazurin in cell culture 
media of untreated cells $\times 100 . \mathrm{LD}_{50}=$ value where the 50 percent cytotoxicity intercepts with the long-chain base concentration on the $\mathrm{x}$-axis. 

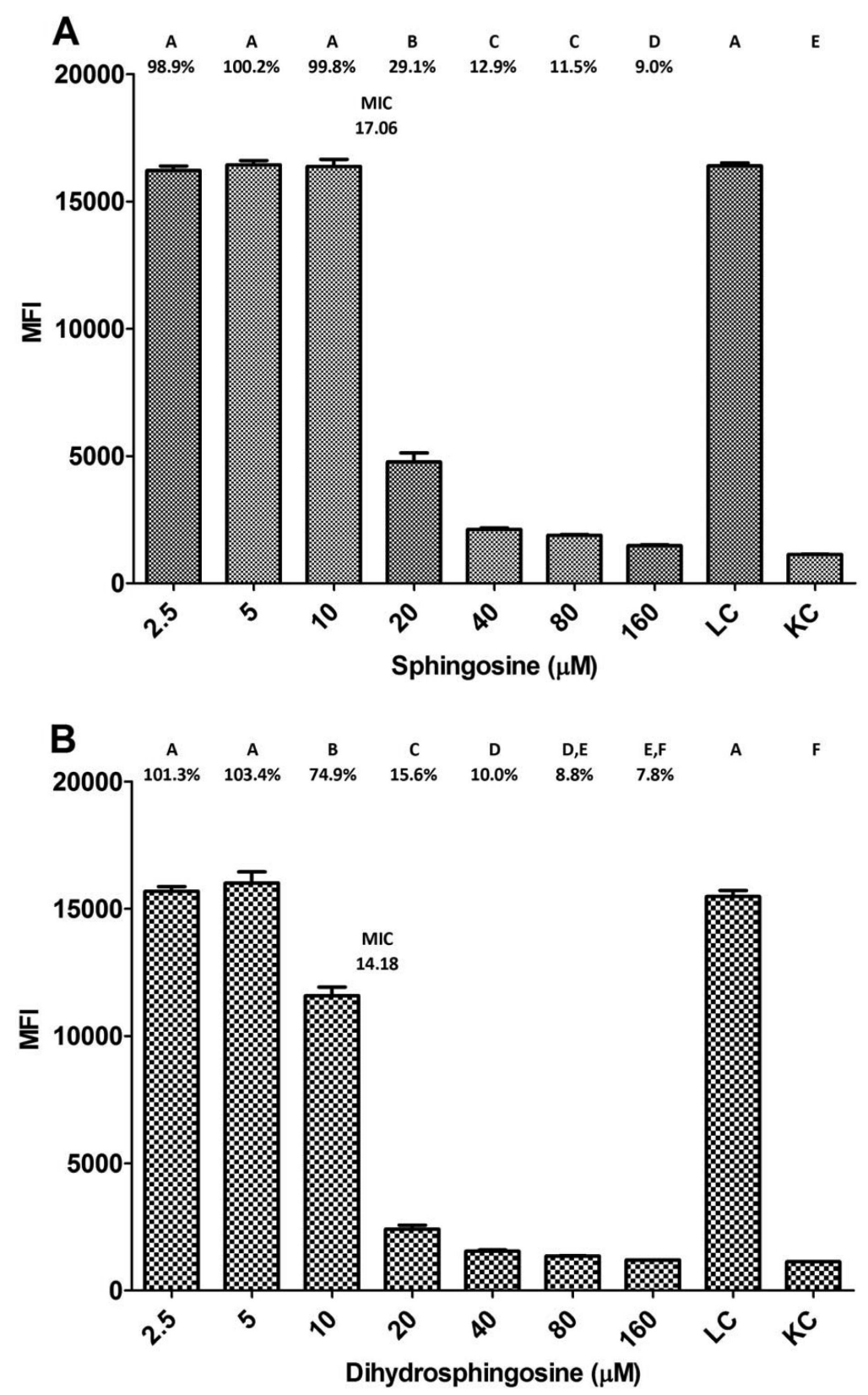

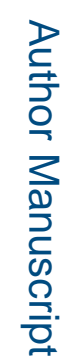



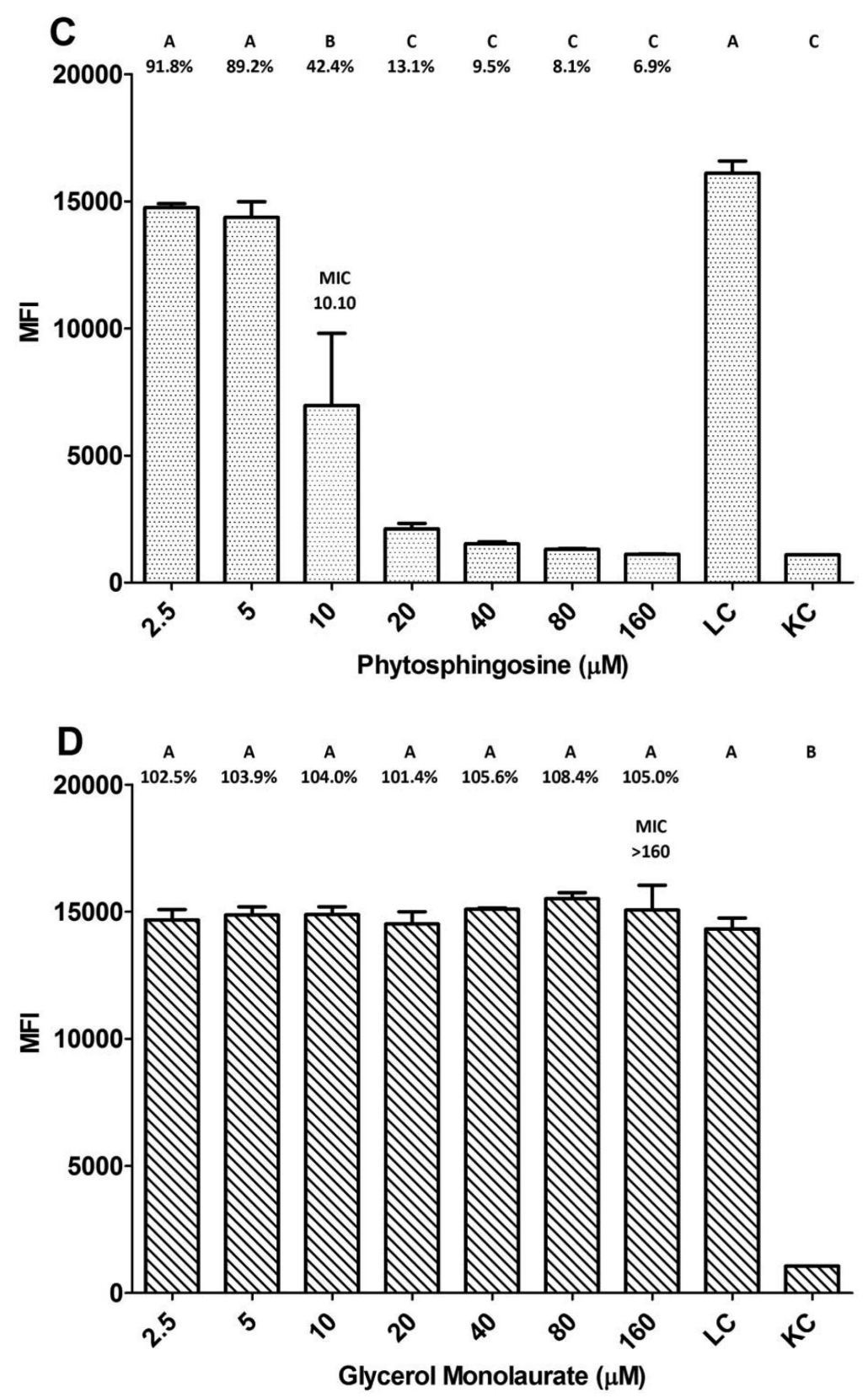

Fig. 5.

Long-chain bases and glycerol monolaurate affect the cell metabolism (conversion of resazurin to resorufin) of a primary human dendritic cell (DC) culture. The graphs below show the median fluorescence intensity (MFI) of resorufin in DC cell culture after $48 \mathrm{~h}$ of exposure to 2.5 to $160.0 \mu \mathrm{M}$ sphingosine (A), dihydrosphingosine (B), phytosphingosine (C), and glycerol monolaurate (D). LGM-3 with resazurin was added to untreated cells and served as live cell controls (LC). LGM-3 with resazurin containing 1\% sodium azide was added to cells and served as killed cell controls (KC). MFI values not connected by the same letter are significantly different. Cytotoxicity $(\%)=$ the MFI of resazurin in cell culture media of cells treated with dilutions of long-chain bases/MFI of resazurin in cell culture 
media of untreated cells $\times 100 . \mathrm{LD}_{50}=$ value where the 50 percent cytotoxicity intercepts with the long-chain base concentration on the $\mathrm{x}$-axis. 

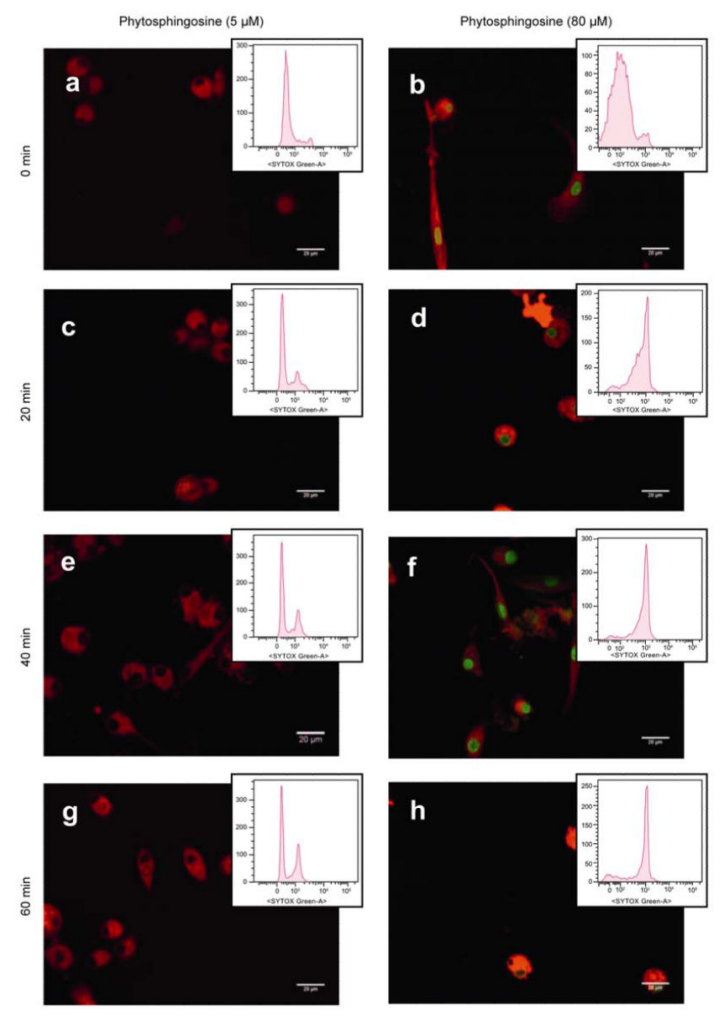

Fig. 6.

A closer examination of phytosphingosine-induced cytotoxicity assessed with confocal microscopy and flow cytometry (inserts). $600 \mu \mathrm{l}$ of LGM-3 containing $1.0 \times 10^{5} / \mathrm{ml}$ viable dendritic cells (DC) were put into chamber slides (confocal microscopy) or $600 \mu \mathrm{LGM}-3$ containing $1.4 \times 10^{5}$ viable $\mathrm{DC} / \mathrm{ml}$ were put into $12 \times 75 \mathrm{~mm}$ round bottom polypropylene tubes (flow cytometry) and first treated with $500 \mathrm{nM} \mathrm{C}_{12}$-Resazurin and $10 \mathrm{nM} \mathrm{SYTOX-}$ Green (LIVE/DEAD® Cell Vitality Assay Kit (Molecular Probes, Eugene, OR) and then with 5.0 or $80.0 \mu \mathrm{M}$ phytosphingosine. In other experiments, cells were treated with sphingosine, dihydrosphingosine, and glycerol monolaurate (results not shown). At 0, 20, 40, and $60 \mathrm{~min}$, adhered cells were examined using a Zeiss 710 LSM confocal microscope (Carl Zeiss Micro Imaging GmbH, Jena, Germany) and suspended cells were examined using a LSR II Flow Cytometer (BD Biosciences, San Jose, CA). Scale bars $20 \mu \mathrm{m}$. 


\section{Table 1}

The effects of long-chain bases on cell metabolism (conversion of resazurin to resorufin) were determined. The range and mean lethal dose $50\left(\mathrm{LD}_{50}\right)$ values of sphingosine $(\mathrm{S})$, dihydrosphingosine (D), phytosphingosine (P), and glycerol monolaurate (GML) are shown for oral keratinocyte (GE), oral fibroblast (GF), dendritic cell (DC), and oral squamous cell carcinoma (SCC) cells.

\begin{tabular}{|c|c|c|c|c|}
\hline & $\mathbf{S}$ & D & $\mathbf{P}$ & GML \\
\hline $\begin{array}{c}\mathrm{GE} \\
(\mathrm{n}=6)\end{array}$ & $\begin{array}{c}17.2->640.0^{a} \\
2.16(0.12)^{b} \\
\text { B,C,D }{ }^{c}\end{array}$ & $\begin{array}{c}15.5->640.0 \\
2.02(0.12) \\
\text { B,C,D }\end{array}$ & $\begin{array}{c}9.0->640.0 \\
1.86(0.12) \\
\text { C,D,E }\end{array}$ & $\begin{array}{c}550.4->640.0 \\
2.79(0.12) \\
\mathrm{A}\end{array}$ \\
\hline $\begin{array}{c}\text { GF } \\
(\mathrm{n}=4)\end{array}$ & $\begin{array}{c}9.0->640.0 \\
1.58(0.15) \\
\text { D,E,F }\end{array}$ & $\begin{array}{c}9.0->640.0 \\
1.53(0.15) \\
D, E, F\end{array}$ & $\begin{array}{c}9.0->640.0 \\
1.54(0.15) \\
D, E, F\end{array}$ & $\begin{array}{c}146.9->640.0 \\
2.54(0.15) \\
\text { A,B }\end{array}$ \\
\hline $\begin{array}{l}\text { SSC cells } \\
(\mathrm{n}=5)\end{array}$ & $\begin{array}{c}9.0-17.1 \\
1.31(0.13) \\
\text { E,F }\end{array}$ & $\begin{array}{c}10.7-32.3 \\
1.19(0.14) \\
F\end{array}$ & $\begin{array}{c}5.8-28.2 \\
1.34(0.13) \\
F\end{array}$ & $\begin{array}{c}255.4-412.7 \\
2.47(0.13) \\
\text { A,B,C }\end{array}$ \\
\hline $\begin{array}{c}\text { DC } \\
(n=2)\end{array}$ & $\begin{array}{l}16.8-287.1 \\
1.85(0.21) \\
\text { B,C,D,E,F }\end{array}$ & $\begin{array}{c}13.9-58.9 \\
1.47(0.21) \\
D, E, F\end{array}$ & $\begin{array}{c}8.1-39.0 \\
1.32(0.21) \\
\text { D,E,F }\end{array}$ & $\begin{array}{c}108.8->160.0 \\
2.14(0.21) \\
\text { A,B,C,D,E }\end{array}$ \\
\hline
\end{tabular}

$a_{\mu \mathrm{M} \text { range of } \mathrm{LD} 50}$

${ }^{b}$ Mean $\log 10$ LD50 (std err)

${ }^{c}$ Values not connected by the same letter are significantly different 